\title{
Narrative Judgments on the Love and Friendship in Julian Barnes' The Sense of an Ending
}

\author{
Liu Maosheng*, Yang Junting \\ Faculty of English Language and Culture, Guangdong University of Foreign Studies, Guangzhou, China \\ Email address: \\ liumaosheng2004@126.com (Liu Maosheng), 1374596143@qq.com (Yang Junting) \\ ${ }^{*}$ Corresponding author
}

To cite this article:

Liu Maosheng, Yang Junting. Narrative Judgments on the Love and Friendship in Julian Barnes' The Sense of an Ending. International Journal of Literature and Arts. Vol. 8, No. 5, 2020, pp. 298-307. doi: 10.11648/j.ijla.20200805.16

Received: August 19, 2020; Accepted: September 8, 2020; Published: September 19, 2020

\begin{abstract}
Julian Barnes is famous in contemporary literary world. His works have attracted many readers all over the world for his variety of writing style and his unceasing exploration of the truth of history and memory. As the Man Booker Prize winning novel in 2011, The Sense of an Ending mainly tells the story of the protagonist Tony Webster's love relationship with Veronica Ford and his friendship with Adrian Finn through recalling the past. Taking the changing relationship among Tony, Veronica and Adrian as the main line, this paper mainly analyzes the different interpretive, ethical and aesthetic judgments and re-judgments made by Tony, the protagonist and the first person narrator, and the reader on the love and friendship in the novel in the light of James Phelan's theory of narrative judgments. Through analysis, this paper shows the organic connections between the three types of narrative judgments, which not only promotes the narrative progression of the novel, but also realizes the perfect integration of the novel in narrative form, narrative ethics and narrative aesthetics. This process shows Barnes' doubts about the reliability of human memory, which provides a better way for readers to understand the novel and appreciate Barnes' superb narrative art.
\end{abstract}

Keywords: Julian Barnes, The sense of an Ending, Narrative Judgments, Narrative Art

\section{Introduction}

\subsection{Julian Barnes and The Sense of an Ending}

Julian Barnes (1946-) is one of the most important British writers in contemporary literary world. As a prolific postmodernist writer, Barnes has published 18 novels, three collections of essays and nine non-fictions. In 1983, Barnes "was selected by the Book Marketing Council as one of the twenty 'Best of Young British Novelists', a list that includes Martin Aims, Pat Barker...Graham Swift" [1]. Since then, he has won numerous literary awards such as Geoffrey Faber Memorial Prize (1985), Gutenberg Prize (1987), and Austrian State Prize for European Literature (2004). Besides, he is the only writer who has won both Prix Femina étranger and Prix Médicis. Taking Barnes's works as a whole, it is impossible to define the typical style of his writings because he refuses to follow the traditional novels' arrangement of plot and the rules of portraying characters. Salient features of his novels are the diversity of topics and writing techniques. He apparently inherited "the experimentalist tradition created by modernist writers like Virginia Woolf and James Joyce" [2].

The Sense of an Ending won the Man Booker Prize in 2011. It is divided into two parts, simply entitled "One" and "Two", both of which are narrated by the protagonist Tony Webster after he retired, lived alone and worked as a volunteer to run the library at the local hospital. Revolving around the changing relationship among Tony, Veronica and Adrian, Tony traces his personal history, which shows his reflection on himself and his growth. Stella Rimington, the head judge of the Man Booker Prize, described the novel as "exquisitely written, subtly plotted and reveals new depths with each reading" [3].

\subsection{James Phelan and His Theory of Narrative Judgments}

James Phelan (1951-) is a leader of the third generation of Chicago School. The Office of Academic Affairs at Ohio State University awarded him "The Distinguished Scholar Award" in 2004 for his achievements and contributions to the rhetorical narrative theory. As Wayne C. Booth and Sheldon 
Sack's student, he develops his teachers' thoughts and puts forward his own theory. Sack once asked a question in the class "Do we read the same book?" [4], which has a great influence on Phelan. Inspired by this, Phelan begins to think about two questions: "Can we read the same book? Can we experience the same book in similar ways?" [4]. On the basis of this, he gives a rhetorical definition of narrative: "somebody telling somebody else on some occasions and for some purpose (s) that something happened" [4].

As a branch of Phelan's theory, narrative judgments show the multilevel and dynamic communications among author, text and readers. There are three types: interpretive judgments, ethical judgments and aesthetic judgments. Phelan claims that "the rhetorical act of telling a story entails a multileveled communication from author to audience, one involving the audience's intellect, emotions, and values (both moral and aesthetic), and that these levels interact with each other" [4]. He also holds that narrative judgments "are crucial to the activation of our multileveled responses and to our understanding of the interrelations among form, ethics, and aesthetics" [4].

The aim of this paper is to appreciate Barnes' superb narrative art through analyzing Tony and readers' different interpretive, ethical and aesthetic judgments and re-judgments on the love and friendship in The Sense of an Ending by employing Phelan's theory of narrative judgments. Through analysis, this paper shows the organic connections between the three types of narrative judgments, which not only promotes the narrative progression of the novel, but also realizes the perfect integration of the novel in narrative form, narrative ethics and narrative aesthetics.

\section{Literature Review}

Since the publication of his first novel Metroland in 1980, Barnes has drawn various attentions from critics. Up to now, Barnes' works have been studied by many scholars, especially his award-winning novel The Sense of an Ending. The research status is as follows.

The studies of Barnes abroad began in the 1980s. They can be generally divided into three types. Firstly, some scholars pay attention to the themes and creative features in Barnes's works. The representatives are the book reviews written by Frank Kermode, John Updike and Peter Brooks. All of them introduce the common themes of women's betrayal in their marriage and Barnes's obsession with French culture. Although these book reviews are not in-depth studies, they open the way to the studies of Barnes's works from the perspectives of feminism and culture to a certain extent. Secondly, the study of narrative occupies a stand in the criticism of Barnes' works. For example, "The oddness of Julian Barnes and The Sense of an Ending" explores the range of responses to oddness-everything in The Sense of an Ending. The author believes that "Barnes is a connoisseur of eccentricity: the figure of the oddball — the crank, hobbyist, or obsessive-frequently takes centre stage in his fiction, often in the guise of a distinctly unreliable narrator. And odd numbers, especially triptychs of inter-related stories and triangular romantic relations, seems to dominant his narrative structure" [5]. Thirdly, there is a trend of studying Barnes' works from the perspective of interdisciplinary research. The most representative in recent years is "Positioning strategies and representation in fictional autobiography: The Sense of an Ending", in which the author analysis the novel by employing spatial positioning strategies and social actors representation which "have been introduced and discussed in visual and political texts" [6]. The purpose is to "disclose the way (s) the narrator-autobiographer positions himself and others in his life story as social factors" and to "investigate whether these strategies can explain the involved social actors' motivations in their interactions" [6].

The studies of Barnes in China began in the late 1990s. They can be generally divided into three types. Firstly, some scholars focus on the thematic studies of Barnes' works. The most representative is "Theses on history in Julian Barnes's novel", in which the author holds that Barnes has responded to Benjamin's philosophy of history in his fictions. Through the use of "citation", Barnes "widens the dimension to contemporary historical reflection in Barnes's exploration of personal history" [7]. Secondly, the study of narrative occupies a stand in the criticism of Barnes' works. For example, in "Ethics of memory narrative in The Sense of an Ending", the author believes that "with episodic memory as both the form and content of its narrative, Julian Barnes's The Sense of an Ending displays the dynamics of memory process through a heterogeneous repetition in narration" [8], which reveals the protagonist's "cognitive error of memory and hence the inherently constructive nature of both memory and identity" [8]. Thirdly, some scholars study Barnes' works by employing different literary criticism theories. "Ethical introspection in The Sense of an Ending" is a case in point. The author analyzes the novel by employing the theory of ethical literary criticism, holding that the novel is about "an ethical tragedy caused by the protagonist's confused ethical identity. Adrian's ethical confusion and Webster's ethical introspection indicates the existence of Sphinx Factors in human mind and its complexity" [9], which lead to "the ethical conflicts among rational will, free will and irrational will" [9].

According to the literature review, it can be seen that as an award-winning novel, The Sense of an Ending has been studied by many scholars from different perspectives in the past ten years. These studies certainly have enriched the interpretation of the novel. However, so far no one has interpreted it from the perspective of James Phelan's theory of narrative judgments. Therefore, this paper is a useful attempt to analyze the novel from this angle.

\section{Interpretive Judgments in The Sense of an Ending}

From Phelan's theory, it can be seen that only characters, narrators and readers can make narrative judgments in a novel 
and 'readers' narrative judgments are usually more objective and more likely to be influenced by narrators' narrative judgments" [4] in the novel. In The Sense of an Ending, Tony recalls his personal history twice, and accordingly characters, narrators and readers will make narrative judgments twice. Tony is the protagonist of the novel and also plays a role as the first person narrator, which means that he performs as an autodiegetic narrator. Therefore, Tony's narrative judgments in the novel stand for both the characters' and narrators' narrative judgments.

\subsection{Interpretive Judgments in Tony's First Recollection}

As the first step of narrative judgments, interpretive judgments refer to "the nature of actions or other elements of the narrative" [4]. It plays an important role in the following ethical and esthetic judgments.

\subsubsection{Tony's False Interpretive Judgments on Love and Friendship}

Taking the novel as a whole, it is clear that Tony tells his life story through recalling his love relationship with Veronica Ford and his friendship with Adrian Finn. As one of the protagonists of the novel, Veronica first appears as Tony's girlfriend then as Adrian's girlfriend, which not only complicates the relationship among them but brings them closely bond together. As the first person narrator, Tony tells the same events twice. However, the results are totally different, which can be seen as the most attractive factor of the novel. Besides, Tony and readers' different narrative judgments on the love and friendship constitute the motivation which promotes the narrative progression of the novel.

In the first part of the novel, Tony recalls his life story through internal focalization. He not only makes false interpretive judgments on the love between Veronica and him and between Veronica and Adrian, but also makes false interpretive judgments on his friendship with Adrian.

Firstly, Tony deems Veronica's behaviors especially Veronica and Adrian are in a relationship soon after they break up as a hurtful thing to him, which leads to Tony's false interpretive judgments on Veronica's love to him.

Tony and Veronica are at the same age and read in the same university. In Tony's eyes, Veronica is very attractive. Her father is a civil servant, which is a very respectable job in the 1960s Britain. And like Adrian, her brother Jack also reads in Cambridge. All of these make Tony very stressful in their relationship. As time goes on, Tony is invited to meet Veronica's family on one weekend. He spends a very unhappy time in Veronica's home. For Tony, it is a painful memory. Veronica's behaviors toward him in front of her family make him feel she does not love him at all. "Veronica didn't even kiss me goodnight that first evening, or make some excuse about towels, and seeing I had everything I needed" [10]. She also leaves Tony alone going for a walk with her father and brother by telling Mrs. Ford that he does not want to get up early in the morning. However, the fact is he knows nothing about this and he never has the habit of sleeping late in the morning. In Tony's eyes, Veronica's behavior of leaving him in a strange place shows that she does not care about him. Besides, it seems that Veronica is always on her father and brother's side when they make fun of him. She never defends him in front of her family. All of these make Tony feel frustrated.

After visiting Veronica's family for one year or so, they have different opinions on their relationship. Veronica asks Tony where their relationship is heading, but Tony refuses to answer it. She says Tony is a coward in the whole process of their relationship, but Tony thinks he is not cowardly but peaceable. According to Tony's memory "After we break up, she slept with me" [10]. When Tony asks Veronica "Did you sleep with me to get me back?" [10], Veronica refuses to answer this question. This is the end of their relationship. Soon after, Veronica and Adrian are in a relationship.

In Tony's opinion, Veronica accepts Adrian as her boyfriend because he is a Cambridge chap like her brother Jack. Besides, it is Veronica who lets Adrian write to him to tell about their current relationship. In his eyes, it is totally veronica's cunning scheme to warn him that "she would be hanging around if I planned on seeing Adrian" [10]. According to this, he feels both he and Adrian are cheated and manipulated by Veronica.

Secondly, Tony deems Adrian's behavior of falling in love with his ex-girlfriend Veronica as a betrayal to their friendship. As Tony's best friend, Adrian's behaviors are a big blow to him. "Betrayal" is Tony's interpretive judgments on Adrian's friendship to him.

In Tony's first recollection, he emphasizes his friendship with Adrian. Along with Colin and Alex, they are a group of four and often hang out together. Among them, Adrian is the smartest one who is highly regarded by their teachers. With no surprise, Adrian goes to Cambridge University with a scholarship, Tony reads history at Bristol, Colin goes to Sussex and Alex into his father's business after they finish their middle school. The four of them are separated and promise to keep a lifelong friendship.

With time goes by, it turns out that Tony pays more attention to Adrian than to Colin and Alex. He wants to get Adrian's attention and approval, and always tells him his best story first. He takes Adrian as his best friend and believes Adrian deems him as his best friend too. As an introvert, Tony often fails in making girlfriend. By chance, he meets Veronica and finally they are in a relationship. He is so happy that he introduces her to Adrian, Colin and Alex in the nearest vacation. However, what he does not think of is that after he and Veronica break up, Adrian and Veronica become boyfriend and girlfriend. It is through him that Adrian and Veronica get to know each other, which makes him very angry. He thinks Adrian and Veronica do not respect him and hurt his feelings. He deems this as a humiliation. According to Tony, although he is angry, he still writes a proper letter back and wishes Adrian good luck when Adrian writes to him to ask his permission to go out with Veronica.

Adrian's behaviors are a big blow to Tony. He never gets in touch with Veronica and Adrian. He tries his best to focus on his study and roams around the United States for six months 
after he graduated from university. When he returns, he gets the news of Adrian's death from his parents. Although Adrian often talks about the Eros and Thanatos, he is a person with a most logic mind among the three of them. Sometimes Tony does not understand him, now his suicide also puzzles everyone around him. To Tony, Adrian is always the "first-class", even his death is "first-class suicide" [10].

From Tony's narration, it can be seen that he admires Adrian's intelligence and attaches great importance to their friendship. Even if Adrian betrays him, he still feels sorry for Adrian's suicide. However, he cannot accept Adrian's behavior of falling in love with Veronica. "Betrayal" is Tony's interpretive judgments on Adrian's friendship to him.

\subsubsection{Readers' False Interpretive Judgments on Love and Friendship}

Phelan emphasizes that "a single action may evoke multiple kinds of judgments", and "because characters' actions including their own judgments, readers often judge characters' judgments" [4]. It can be inferred that readers' judgments may different from the characters' because they stand outside the story and discourse level. But more importantly, readers' judgments are often influenced by the characters' judgments in the novel.

Due to the limitation of the first person narrator, all the information readers get is from Tony's narration. Influenced by Tony's interpretive judgments, readers' interpretive judgments on Veronica and Adrian's behaviors are also inclined to be negative. But readers also have their own interpretive judgments, which are not totally in accordance with Tony's. The different interpretive judgments on the same events form the tension between the narrator and readers, which promotes the progression of the novel in the discourse level.

Tony's interpretive judgments on Veronica's behaviors influence readers' judgments. According to Tony's memory, Veronica always looks through his record collection "with an occasional flickering smile and a more frequent frown" [10], which makes readers feel Veronica despises Tony's taste. And the very behavior of falling in love with Adrian soon after they break up makes readers feel that she indeed does not love Tony at all.

In the face of love and friendship, Adrian finally chooses the former. Adrian's behavior betrays their friendship. This is Tony's interpretive judgments on Adrian's behaviors. For readers, on the one hand, they may have the inclination to agree with him. When Tony knows the news of Adrian's death, he swears the word "shit" for the first time in front of his parents. This is his instinctive reaction, which shows Tony indeed takes Adrian as his best friend. From this point, Adrian's behavior of falling in love with Tony's ex-girlfriend Veronica seems to be not so acceptable. But, on the other hand, Tony's motivation in making friends with Adrian may not so pure. He recalls "We wanted his attention, his approval; we courted him, and told him our best stories first; we each thought we were - and deserved to be-closet to him" [10]. He wants to make friends with Adrian because Adrian is the most excellent among them. If he is Adrian's best friend, other students will admire him, which satisfies his vanity.

In a word, for readers, Tony's interpretive judgments are fair in general, but they still hold different opinions on part of his judgments, which forms the tension between the narrator Tony and readers. Which interpretive judgments are correct? What is the truth? In order to solve these problems, this paper will discuss Tony's second recollection of the same events in part two of the novel.

\subsection{Interpretive Judgments in Tony's Second Recollection}

In the first part of the novel, Tony briefly recalls his life story and makes interpretive judgments on the love and friendship in the novel. However, in the beginning of the second part of the novel, Tony receives a lawyer's letter which makes him recall the past again. In his second recollection, he is surprised to find that almost all the interpretive judgments he made in his first recollection are wrong. Therefore, Tony begins to have a reflection on himself and makes interpretive re-judgments on the love and friendship in the second part of the novel. So does readers.

\subsubsection{Tony's Interpretive Re-judgments on Love and Friendship}

In the beginning of the second part of the novel, Tony receives a letter informs him that Mrs. Ford, his ex-girlfriend's mother, left him five hundred pounds and two documents, which include Adrian's dairy. Besides, she also apologizes for the ways her family treated him and tells Tony that she thinks "the last month of Adrian's life were happy" [10]. All of these puzzle Tony greatly. He determines to find out the truth, but is only to be told that Veronica took the dairy away. Therefore, he tries to get in touch with Veronica. When he finally meets Veronica and has several conversations with her, he finds that due to the limited point of view, most of his memories are full of loopholes. In his memory, Adrian and Veronica betray him and fall in love with each other. However, the truth is Adrian falls in love with Mrs. Ford and they even have a child who is weak in intelligence. He begins to make interpretive re-judgments on the love and friendship.

Firstly, Tony's interpretive judgments on Veronica's behaviors change. He realizes that Veronica's love to him is totally misinterpreted by him. He misinterprets the relationship between Veronica and Adrian and between Veronica and the abnormal child. Therefore, he has a reflection on himself and no longer sees himself as a victim in his love relationship with Veronica.

In the second part of the novel, Tony receives the photocopy of the letter he writes back to Adrian forty years ago. In his first recollection, he says he writes properly back. But the truth is just the opposite. In his malicious letter, he calls Veronica "bitch" and speaks ill of her by saying "I can see your tactics - isolate him, cut him off from his old friends, make him dependent on you...it's just a question of whether you can get pregnant before he discovers you're a bore" [10]. When Tony knows the truth, he feels remorseful and begins to have a reflection on his deeds: "I wonder if I'd been awkward, pushy, 
selfish" [10].

Besides, in Tony's first recollection, he says Veronica despises his musical taste and never dances with him. However, now he recalls "But there she was, leaping about in a way that made me suspect she'd been to ballet classes, her hair all over her face and her calves tense and full of strut" [10] Veronica indeed dances with him and the picture of Veronica's dance is a very beautiful scene in his eyes. He also remembers the long-buried details of that distant weekend with the Ford family. Actually Veronica does not treat him indifferently. "Veronica did more than just come upstairs with me. She said 'I'm going to walk Tony to his room' and took my hand in front of her family" [10]. When they get to Tony's room, Veronica kisses him gently and says good night to him. Veronica's behaviors show that she loves Tony and wants him to get the approval of her family.

Even worse, Tony misinterprets the relationship between Veronica and Adrian and between Veronica and the child who appears in the second part of the novel. When Tony first meets the child, he realizes the child is weak in intelligence. According to his assumption, he thinks Adrian and Veronica are in a relationship all the time after their breakup. Therefore, he deems the child as Adrian and Veronica's son. It is not until the end of the novel that he knows the child is actually Adrian and Mrs. Ford's son. Veronica is also a victim in the relationship between Adrian and Mrs. Ford. Up to now, Tony totally changes his interpretive judgments on Veronica's behaviors. He realizes that Veronica loves him at least at that time.

Secondly, Tony's interpretive re-judgments on Veronica's behaviors also lead him to rethink about his friendship with Adrian. This time, he changes his interpretive judgments on Adrian's behaviors. He no longer deems Adrian's behaviors as a betrayal to their friendship. Actually, Adrian attaches great importance to their friendship. The woman he falls in love with is not Veronica but her mother Mrs. Ford.

Different from his previous memory, in the letter, he tells Adrian that "even her own mother warned me against her" [10]. He also advises Adrian to ask Mrs. Ford about Veronica. Now, he realizes maybe it is his suggestion that increases the communication between Adrian and Mrs. Ford that leads to the love affair between them. More coincidentally, just as he cursed in the letter, Adrian and Mrs. Ford indeed have an abnormal child. He reads this letter for several times and could scarcely deny its ugliness. He now understands that he writes the evil letter because he is jealous of Adrian. However, the truth is Adrian and Veronica did not fall in love at that time. He misinterprets the relationship between them for 40 years. Now, Tony realizes that Adrian never betrays their friendship.

However, when he knows Adrian commits suicide before the child's birth, he begins to suspect the reason of Adrian's suicide. He no longer sees Adrian's behaviors as "first-class". Adrian's death reminds him of Robson, one of their schoolmates in middle school, who gets his girlfriend pregnant but unable to face the consequences and finally chooses to take an easy way out-he hangs himself in the attic. He finally comes to a conclusion that Adrian's suicide is "no more than a version of Robson" [10].

Through Tony's second recollection, he makes interpretive re-judgments on the love and friendship in the novel. He changes his prejudice against other people and has a reflection on himself. Just as he says in the novel: "the longer life goes on, the fewer are those around to challenge our account, to remind us that our life is not our life, merely the story we have told about our life" [10].

\subsubsection{Readers' Interpretive Re-judgments on the Love and Friendship}

As readers, their interpretive judgments on the love and friendship also change with Tony's second recollection of the same events. They realize that due to the influence of Tony's first recollection, they made false interpretive judgments on the love and friendship. Therefore, they begin to make interpretive re-judgments on them.

Firstly, readers' interpretive judgments on Veronica's love to Tony change. They hold that it is Tony's awareness of self-protection and Veronica's refusal of communication that lead to Tony's misinterpretation of Veronica's love on him.

Tony's self-protection leads to his false interpretive judgments on Veronica's behaviors, which also influences readers' judgments. In Tony's first recollection, he says Veronica sleeps with him after their break up. But the truth is Tony breaks up with Veronica after they sleep. When Veronica calls him "you selfish bastard" [10], Tony's awareness of self-protection leads him to find excuses for himself. It is clear that Veronica chooses to have sex with him because she wants to continue their relationship. Besides, after knowing Veronica does not live an easy life for the past 40 years because she needs to take care of her abnormal brother who is her mother and her ex-boyfriend's son, readers' interpretive judgments on Veronica's behaviors totally change. Veronica's deeds show that she does not leave Tony just because Adrian is more excellent than him.

For readers, Veronica's refusal of communication also leads to Tony's false interpretive judgments on her love to him. When Tony asks Veronica if she sleep with him to get him back, Veronica refuses to answer it, which is the main reason for their breakup. And in Tony's second recollection, he misunderstands the abnormal child is Veronica and Adrian's son. Veronica does not explain it either. She does not care what Tony think of her. This is the main reason for Tony and readers' misinterpretation on her relationship with Adrian.

Secondly, readers also make interpretive re-judgments on Adrian's behaviors. The behavior of falling in love with Mrs. Ford shows Adrian does not betray their friendship. But the behavior of committing suicide shows Adrian's irresponsibility for Mrs. Ford and the child.

In the second part of the novel, readers know the real reason of Adrian suicide. They make negative interpretive judgments on his deeds. Adrian falls in love with Mrs. Ford and cannot face the consequences of Mrs. Ford's pregnancy, so he chooses to commit suicide. He never thinks of Mrs. Ford and the unborn child. It is dangerous for Mrs. Ford to give birth to a child at her age. And it turns out the child is not as healthy as 
others. From this perspective, Adrian's behavior of committing suicide is irresponsible.

In summary, through Tony's second recollection of the same events, both Tony and readers make interpretive re-judgments on the love and friendship. During this process, readers feel Barnes' superb narrative form. The use of detective novel's pursuit mode and the setting of suspense make the novel more attractive and also provide readers with great motivation during their reading process. In Phelan's opinion, "interpretive judgments will more or less influence ethical judgments and aesthetic judgments and even overlap with them" [11]. Along with Tony's interpretive judgments, he actually makes different kinds of ethical judgments on the love and friendship, and his ethical judgments also influence readers' ethical judgments.

\section{Ethical Judgments in The Sense of an Ending}

Ethical judgments refer to "the moral values of characters and actions" [4]. Phelan emphasizes that they are "proceed from inside out rather than outside in because individual narrators in a novel often establish their own ethical standards to guide readers to a particular ethical judgments" [4]. That is to say, "ethical judgments involve two steps: reconstruction and evaluation" [4]. In other words, "unlike philosophical ethicists or moral critics, rhetorical critics do not criticize narrative works by using the existing ethical systems, and they try to reconstruct the ethical principles within narrative works" [11].

\subsection{Ethical Judgments in Tony's First Recollection}

As we mentioned above, ethical judgments involve two steps: reconstruction and evaluation. Therefore, how to reconstruct the novel's ethical principles become a very important question. To answer this question, we need to pay attention to Phelan's concept of "ethical positions". In Living to Tell about It: A Rhetoric and Ethics of Character Narration, Phelan puts forward four kinds of "ethical positions": characters' ethical position, narrator's ethical position, implied author's ethical position, and flesh-and-blood readers' ethical position. The four of them are interact with each other [4].

\subsubsection{Tony's False Ethical Judgments on Love and Friendship}

According to Phelan, there is a close connection between interpretive judgments and ethical judgments and they have a great possibility to "overlap with each other" [4]. In other words, Tony's interpretive judgments on love and friendship will influence his ethical judgments on them. In the first part of the novel, Tony recalls his personal history. During the process, he falls into ethical dilemma and finally makes what he calls as "rightful" ethical judgments on the main characters.

Firstly, in Tony's first recollection, his interpretive judgments on Veronica's behaviors are negative. He deems himself as a victim in the relationship with Veronica, so his ethical judgments on Veronica's love to him are also negative.

Tony constantly mentions about Veronica's deeds in their relationship to show how immoral her deeds are. He tells readers the whole process of their relationship including where they meet, how they become boyfriend and girlfriend and why they break up to show that Veronica's deeds hurt him deeply. After their breakup, Tony seems to be a different person for some time. He used to be so shy that he would hardly do anything against the school discipline. But now, he "falls in with a different group, drank systematically, smoked a bit of dope, and thought about very little" [10]. And after graduation, he also roams around the United States for six month so that he can forget the breakup. In short, Tony thinks Veronica's deeds are immoral. This is Tony's ethical judgments on Veronica's love to him.

Secondly, in Tony's first recollection, "betrayal" is his interpretive judgments on Adrian's behaviors. He thinks Adrian betrays their friendship, so his ethical judgments on Adrian's friendship to him are also negative.

Tony deems Adrian as his best friend. However, after he and Veronica break up, Adrian begins to go out with Veronica, which is so unacceptable for Tony. Therefore, in his following narration, he compares the behaviors of Adrian and himself in terms of this matter. According to his narration, he receives the letter Adrian writes to him asking his permission to go out with Veronica and deals with Adrian's "immoral action" in a proper way. He does not choose to revenge or have any verbal attack on them. He just writes back with very polite language and gives them best wishes. Through contrast, Tony puts himself in a very high moral position and Adrian who as the object of his contrast is naturally immoral.

All in all, Tony thinks both Veronica and Adrian's behaviors are immoral. Their behaviors hurt him deeply, so his ethical judgments on the love and friendship are negative.

\subsubsection{Readers' False Ethical Judgments on the Love and Friendship}

As the narrator of the novel, Tony's negative ethical judgments on the love and friendship have the potential to be the basis of readers' ethical judgments, but readers may have different opinions. Besides, the implied author Barnes carefully guides readers to make more complex judgments through his skillful narrative strategies.

Firstly, influenced by Tony's negative ethical judgments on Veronica, at first, readers' may agree with his ethical judgments on Veronica's love to him. But later, readers suspect the truthfulness of Tony's judgments.

In Tony's recollection, some of his narrations are not in accordance with each other. In Tony's first recollection, he thinks Veronica is nice, but very soon he changes his opinion: "well, I probably would have found any girl who didn't shy away from me nice" [10]. From this perspective, readers may infer that Tony is not really love Veronica. The later events confirm this. After they go out for some time, Tony wants to have sex with Veronica. However, when Veronica refuses him, he feels disappointed and thinks that "Colin and Alex had 
fixed themselves up with girlfriends who didn't have any exclusion-zone polices - or so their hints implied" [10]. This indicates that Tony just wants a girlfriend to show off in front of his friends. However, after Veronica has sex with him, he suspects Veronica's virginity and thinks she is not as pure as he has thought before. He even thinks how stupid he is to believe Veronica is a virgin. But the truth is Veronica never says she is a virgin. It is only Tony's assumption. When the fact is not in accordance with his assumption, he is angry and thinks Veronica cheated him. Therefore, he finally chooses to break up with Veronica.

Since literature is the product of history, the change of ethical environment will lead to the misreading and misjudgment of literary works [12]. Therefore, it is necessary to take the novels' background of the 1960s into consideration. The 1960s is an era of great social change. At that time, many young people in Europe and the United States began to embrace a set of values that completely different from their parents. They were rather free and open in sex. Besides, Tony also says "I wasn't exactly a virgin, just in case you were wondering" [10]. Since he is not a virgin, there is no sense to require Veronica must be a virgin. All of these show that Tony's ethical judgments on Veronica's love to him are based on his false standards of values. For readers, this cannot prove Veronica's deeds are immoral.

Secondly, as for Adrian, readers may agree with Tony's negative ethical judgments on him at first, but under the implied author Barnes's guidance, readers reconstruct the ethical standards within the novel and change their ethical judgments on Adrian.

Adrian's behavior of falling in love with Veronica make him falls into an ethical dilemma. Writing to ask Tony's permission to go out with Veronica is Adrian's moral scruples to Tony. After all, they are best friends. From this point of view, Adrian's behavior makes readers feel he is immoral. However, from Adrian's perspective, at least his purpose of writing the letter is out of goodness. He wants to tell Tony the news by himself and wants Tony to understand him. If Tony condemns his behaviors, maybe he will reconsider his relationship with Veronica. This shows that Adrian cares about Tony's feelings and takes their friendship seriously. Actually, if Adrian does not write this letter, we cannot say he does anything wrong. After all, Tony and Veronica are not in a relationship now. From this perspective, Adrian's behaviors seem not so unacceptable. Readers' ethical judgments on him also become relatively positive.

All in all, Tony and readers' different ethical judgments on the love and friendship form the tension in the novel, which leads them to make further ethical judgments in Tony's second recollection.

\subsection{Ethical Judgments on Tony's Second Recollection}

In the second part of the novel, Tony recalls the same events again and the truth of them gradually shows up, which leads to the change of Tony and readers' ethical judgments on the love and friendship in the novel.

\subsubsection{Tony's Ethical Re-judgments on Love and Friendship}

Firstly, it is not until the end of the novel that Tony finally realizes his misinterpretation of Veronica's love to him and Veronica's relationship with Adrian and the child. He begins to change his opinions and makes positive ethical judgments on Veronica.

In Tony's second recollection, he knows that Veronica's mother is the person Adrian falls in love with. Without telling Tony the truth, Veronica takes care of Adrian's son or we can say her half brother for forty years. She has to pay money for the care-in-the-community home to look after the abnormal child. Maybe it is for this reason Veronica remains single. Now, Tony feels remorseful for the letter's ugly contents. He is not being fair to Veronica all the time whether in their relationship or after the end of their relationship. Finally, Tony realizes that Veronica is the real victim among him, Adrian and Mrs. Ford.

Secondly, Tony's ethical judgments on Adrian in his second recollection are still inclined to be negative, but the reasons are different. In Tony's second recollection, he realizes it is his jealousy and resentment that cause him to make false ethical judgments on Adrian. He feels "a more general remorse-a feeling somewhere between self-pity and self-hatred-about my whole life" [10]. He suspects he is the trigger of the whole thing and even related to Adrian's suicide. He regrets for his immoral deeds. He no longer puts himself in a very high ethical position.

As for Adrian's suicide and his relationship with Mrs. Ford, Tony's ethical judgments on Adrian are inclined to be bad. He thinks Adrian's suicide is "nothing to do with cleverness; and even less with moral courage...he was afraid of the pram in the hall" [10]. Adrian's suicide also leads him to think of Robson who makes her girlfriend pregnant and finally chooses to suicide to avoid facing the moral criticism. He thinks there are similarities between them. Up to now, Tony's ethical judgments on Adrian become negative. Accordingly, readers also make ethical re-judgments on Adrian's deeds.

\subsubsection{Readers' Ethical Re-judgments on the Love and Friendship}

Readers' previous ethical judgments on the main characters are not absolutely good or bad. There are doubts that need to be confirmed. In the second part of the novel, as the truth of the past comes to light, readers make ethical re-judgments on the love and friendship.

Firstly, readers make positive ethical judgments on Veronica's behaviors. Adrian and her mother's love affair is a big blow to Veronica let alone the birth of the child. Adrian should be her boyfriend, but he becomes her step father to some extent. Adrian's intervention shatters her family. Her father's death may also have something to do with this. At that time, Veronica falls into an ethical dilemma. Adrian kills himself and leaves her mother as an elderly pregnant woman and the child turns out to be abnormal. It seems immoral if Veronica chooses to leave her mother alone to take care of the abnormal child. They need her help and she cannot deny the kinship between them. Finally, Veronica chooses to stay. She helps her mother to 
take care of the child and remains single. At this point, readers feel sympathy for Veronica.

In the face of ethical dilemma, Veronica chooses the right side. Her deeds belong to a more highly ethical level, which forms a clear contrast with Tony's selfishness and Adrian's evasion of responsibility. This leads readers to make positive ethical judgments on Veronica.

Secondly, readers' ethical judgments on Adrian also change. Although he does not betray his friendship with Tony, his behaviors of falling in love with Mrs. Ford and committing suicide cause readers to make negative ethical judgments on his deeds.

In the novel, the implied author Barnes does not tell readers whether Adrian knows about the existence of the child. But whether Adrian knows it or not, the very essence of falling in love with Mrs. Ford violates the general ethical standard. Mrs. Ford has her own family. Although she does not speak a lot in the family, she indeed lives a peaceful life. In other people's eyes, they are a happy family. Anyway, Adrian's deeds make him become a destroyer of other people's family. In Mrs. Ford's will, she tells Tony that she thinks Adrian is happy in the last month of his life. Readers may doubt that since he is happy, why does he kill himself? There is a great possibility that the child is the main reason for his suicide. When he knows Mrs. Ford is pregnant, he realizes the consequence he made. He cannot face the ethical predicament, so he chooses an easy way out. He never considers the circumstance Mrs. Ford faced, which shows his selfishness and irresponsibility.

Through Tony's recollections of the same events, the implied author Barnes continuously guides readers to make different kinds of ethical judgments on the main characters. Readers also constantly reconstruct and evaluate the ethical principles during their reading process and finally make right ethical judgments on the main characters.

As the first person narrator of the novel, the unreliability of Tony's narration delays the disclosure of the truth. The photocopy of Adrian's dairy and the appearance of Adrian's son reverse Tony and readers' interpretation of the love and friendship in the novel. They finally make the right ethical judgments, which realize the integration of readers and Tony's ethical judgments.

To a certain extent, literature is originally created for ethical and moral purposes [13]. Through the analysis of Tony and readers' ethical judgments, Barnes's narrative ethics are showed clearly to us. This also shows Barnes' ethical concern for modern people's life.

\section{Aesthetic Judgments in The Sense of an Ending}

Aesthetic judgments refer to "the artistic quality of the narrative and of its parts" [4]. Like ethical judgments, "aesthetic judgments also involve a two-step process of reconstruction and evaluation" [4]. And "rhetorical aesthetics does not start with a hierarchy of pre-approved aesthetic principles. Instead, it seeks to understand the aesthetic principles upon which the individual work is constructed and the particular execution of those principles, and it then moves to make an evaluation of the overall aesthetic achievement" [4]. Phelan also claims that different from interpretive and ethical judgments, "aesthetic judgments are both first-order and second-order activities" [4]. They are first-order because "we make judgments of quality that exist alongside our interpretive and ethical judgments" [4], and they are second-order because "they follow from and depend on our interpretive and ethical judgments" [4].

From the discussion, it is clear that different from interpretive and ethical judgments, only readers can make aesthetic judgments in a novel. And readers' interpretive and ethical judgments provide a foundation for readers' aesthetic judgments.

\subsection{Readers' First-order Aesthetic Judgments}

According to Phelan, "first-order aesthetic judgments may also be thought of as threshold judgments: if our assessment of an author's technical mastery does not reach a certain threshold, we are likely to stop reading unless there are other compelling reasons to continue" [4]. To explain first-order aesthetic judgments in a more specific way, it refers to "readers' continuous assessment of the writing skills used in the narrative work" [4], which can be seen as the process of readers' reconstruction of the aesthetic principles in the work.

As a postmodernist writer, Barnes is famous for his use of narrative strategies in writing novels. The Sense of an Ending is a case in point. Unlike traditional novels, this novel is short and includes only two parts. The narrator tells readers the same events for two times in the first and second part of the novel respectively. Besides, Barnes also sets suspense in the beginning of the second part of the novel, which provides readers great motivation to read the novel. Through the process of readers' interpretive and ethical judgments, it can be seen that there are three striking writing techniques used in the novel: repeating narrative, multiple-focalization and unreliable narrator.

According to Gérard Genette, in terms of "frequency", repeating narrative refers to "narrating $\mathrm{n}$ times what happened once" [14]. Tony recalls the same events both in the first and second part of the novel, which is a kind of repeating narrative. In terms of "focalization", Genette divides it into three types: zero focalization, internal focalization and external focalization. Among them, multiple-focalization belongs to the second type. It means that "the same event may be evoked several times according to the point of view of several letter-writing characters" [14]. The photocopy of Adrian's dairy, the letter Tony writes to Adrian forty years ago, the worker in the care community center and even the appearance of Adrian's son all provide new perspectives for Tony to find the truth of the past events. This is multiple-focalization. As for "unreliable narrator", Booth defines it "I have called a narrator reliable when he speaks for or acts in the accordance with the norm of the work (which is to say the implied author's norms), unreliable when he does not" [15]. With Tony's second recollection of the same events, he realizes that he has 
misjudged other characters. Of course this is the implied author's design, which makes readers realize the unreliability of Tony's narration. Through the use of the three writing techniques, the implied author Barnes guides readers to judge the narrator's reliability and to see the essence of the novel so that they can make right judgments on the love and friendship. It also helps readers to reconstruct the aesthetic principles during their reading process and then make overall evaluation on the narrative aesthetics of the novel.

However, what are the narrator and implied author's purposes of telling the story by using the three narrative strategies? What effects will they produce? These two questions are concerned with the readers' second-order aesthetic judgments in the novel, which is the second step of aesthetic judgments.

\subsection{Readers'Second-order Aesthetic Judgments}

To explain second-order aesthetic judgments in a more specific way, it refers to "the judgments we make about the overall quality of the experience offered by the narrative in the novel, both as we read and after we finish reading" [4]. Through Barnes's skillful use of repeating narrative, multiple-focalization and unreliable narrator, readers will make an evaluation on the narrative aesthetic of the novel.

Tony's first recollection mainly reflects the conflict relationships among Tony, Veronica, and Adrian, which forms the "instability" at the story level. By instability, it refers to "the conflictual relations between or within characters that lead to complications in the action and sometimes eventually to resolution" [16]. The instability forms the motivation which promotes readers to continue to read the second part of the novel.

In Tony's second recollection, he recalls the same events again. According to Phelan, "second-order aesthetic judgments are dependent on and follow from all three primary-level judgments - not just the aesthetic but also the interpretive and the ethical" [4]. In Tony's first recollection, he tries to describe himself as a victim and misleads readers to make negative interpretive and ethical judgments on the love and friendship in the novel. But readers' narrative judgments are not totally in accordance with Tony's, which forms "tension" in the novel. By tension, it refers to "relations involving significant gaps in values, beliefs, or knowledge - between authors and readers or narrators and readers" [16]. This also provides readers strong desire to continue their reading until they find the truth of all things.

In the second part of the novel, Barnes's use of multiple-focalization provides new perspectives to see the past things, which proves that Tony is an unreliable narrator. Accordingly, Tony's previous interpretive and ethical judgments on the love and friendship are wrong. In other words, it is totally the implied author Barnes' rhetorical design. Barnes uses Tony's unreliable narration to misguide readers and to provoke instability and tension in the novel, which makes the novel more attractive. In the end of the novel, Tony realizes his misinterpretations on the main characters' behaviors, so he begins to make re-judgments on them. Finally, he has a better understanding to himself, Adrian and Veronica. Up to now, all the instability and tension are solved. The implied author Barnes successfully makes the novel to the end.

For readers, after making a series of wrong interpretive and ethical judgments under the guidance of the narrator and implied author, they begin to change their previous judgments and make re-judgments on the love and friendship. More importantly, readers begin to make evaluation on the rhetorical designs of the whole novel. They re-judge the rhetorical effects of the author's use of repeating narrative, multiple-focalization and unreliable narrator, and then make positive aesthetic judgments in the novel.

Through the perfect use of the three narrative strategies, Barnes realizes both the narrator's and his own purposes. For the first person narrator Tony, he finally finds the truth of all things and has a reflection on himself. Just like he says "You get towards the end of life-no, not life itself, but of something else: the end of any likelihood of change in that life" [10]. In the end of the novel, Tony feels a sense of an ending: an ending of all the past things, especially the ending of his relationship with Veronica. But the ending also symbolizes a new beginning. No matter what happens life will still go on. The only difference is Tony has a better understanding of himself now. After experiencing the moral weakening, he changes his opinions on himself and other people. Now, he has more tolerable attitude towards people. With this in his heart, he can still live a meaningful life in the future. This shows Barnes's positive attitude towards life.

As for readers, Barnes's perfect use of the three narrative strategies not only challenges their reading expectation but also brings them a pleasant reading experience. Through Barnes' superb narrative strategies, readers feel the organic combination among interpretive, ethical and aesthetic judgments. More importantly, Barnes also shows readers that his real purpose is not simply to talk about the friendship and love. Under the surface of them, he actually discusses the authenticity of memory through the excavation of the new historical materials. This shows that no matter how accuracy you think your memory is, there are always subjective factors in it. Tony's recollections and narrative judgments and re-judgments on the love and friendship are the perfect examples of this view.

In a word, through aesthetic judgments, readers appreciate Barnes's exquisite narrative skills. Tony recalls the same events twice in the novel, which is Barnes' ingenious design and can be seen as a kind of self-deconstruction. This is also one of the reasons for the novel to win the Man Booker Prize in 2011.

\section{Conclusion}

As a Man Booker Prize winning novel, Barnes' The Sense of an Ending not only talks about love and friendship but also discusses the authenticity of memory. In the light of James Phelan's narrative judgments theory, this paper mainly analyzes Tony and readers' interpretive, ethical and aesthetic 
judgments and re-judgments on the love and friendship in the novel. To sum up, firstly, the tension between misinterpretation and truth promotes the progression of the novel on the whole. Secondly, the organic combination among interpretive, ethical and aesthetic judgments realizes the implied author's narrative purposes, which promotes readers to make right narrative judgments. Through breaking readers' reading expectation on the novel, Barnes skillfully increases readers' pleasure of reading. Finally, through the analysis of Tony and readers' narrative judgments in the novel, this paper reveals the mutual connections among the three types of narrative judgments, which provide readers with a new and better way to understand the novel and appreciate Barnes's superb narrative art.

\section{References}

[1] Guignery, Vanessa \& Roberts, Ryan, eds. Conversations with Julian Barnes [M]. Jackson: The University Press of Mississippi, 2009.

[2] Qu, Shijing \& Ren, Yiming. A History of Contemporary British Fiction [M]. Shanghai: Shanghai Translation House, 2008.

[3] Masters, Tim. Man Booker Prize Won by Julian Barnes at Fourth Attempt [N]. BBC News. BBC. 18 Oct., 2011.

[4] Phelan, James. Experiencing Fiction: Judgments, Progressions, and the Rhetorical Theory of Narrative [M]. Columbus: The Ohio State University Press, 2007.

[5] Greaney, Michael (2014). The oddness of Julian Barnes and The Sense of an Ending. English, 63 (242): 225-240.
[6] Farsi, Roghayeh (2019). Positioning strategies and representation in fictional autobiography: The Sense of an Ending. Anglia, 137 (1): 84-104.

[7] Li, Hongqing (2018). Theses on history in Julian Barnes's novel. Foreign Languages Research, 35 (3): 92-98, 112.

[8] Chen, Bo (2018). Ethics of memory narrative in The Sense of an Ending. Contemporary Foreign Literature, 39 (1): 96-103.

[9] Zhang, Lainqiao (2015). Ethical introspection in The Sense of an Ending. Contemporary Foreign Literature, 36 (3): 70-76.

[10] Barnes, Julian. The Sense of an Ending [M]. New York: Vintage Books, 2012.

[11] Shang, Biwu (2010). A maternal love misread: Narrative Judgments in Toni Morrison's A Mercy. Foreign Literature Studies, 32 (4): 60-69.

[12] Nie, Zhenzhao (2014). Introduction to Literary Ethical Criticism [M]. Beijing: Peking University Press, 2014.

[13] Liu, Maosheng (2018). The ethical tradition in Bernard Shaw's theatrical narrative. Foreign Literature Studies, 40 (3): 67-76.

[14] Genette, Gérard. Narrative Discourse: An Essay in Method [M]. New York: Cornell University Press, 1980.

[15] Phelan, James \& Rabinowitz, Peter, eds. A Companion to Narrative Theory [M]. Hoboken: Blackwell Publishing Ltd, 2005.

[16] Phelan, James. Narrative as Rhetoric: Technique, Audiences, Ethics, Ideology [M]. Columbus: The Ohio State University Press, 1996. 